\title{
Music and Copyright
}

\author{
Second edition
}

Edited by Simon Frith and Lee Marshall

Edinburgh University Press 
(C) in this edition Edinburgh University Press, 2004

(C) in the individual contributions is retained by the authors

Transferred to digital print 2009

Edinburgh University Press Ltd

22 George Square, Edinburgh

Typeset in Ehrhardt

by Hewer Text Ltd, Edinburgh, and

printed and bound in Great Britain by

CPI Antony Rowe, Chippenham and Eastbourne

A CIP record for this book is available from the British Library

ISBN 0748618120 (hardback)

ISBN 0748618139 (paperback)

The right of the contributors

to be identified as authors of this work

has been asserted in accordance with

the Copyright, Designs and Patents Act 1988. 